\title{
PEACEFUL LOCAL ELECTION, PEACEFUL INDONESIA
}

Simultaneous Local Elections (Pilkada) of the second phase will start soon. Stages of the campaign is not yet started, but the tricks and intrigue,strategies and programs race, had begun even before the start flag hoisted. The indication of this simultaneous local elections of the second phase is more crowded, have started to appear on the action of campaign team and supporters.

The festive time is marked by the ongoing local elections in DKI Jakarta as one barometer of democratic life in Indonesia. As an area center of power, tricks and intrigues conducted by campaign teams enough to make supporters, opponents, as well as ordinary people hold their breath, so it had appeared the comments, what was so severe ways that used to gain power?

One thing that should be wary as part of the dynamics of democracy and at the same time vulnerable to public order and security is the issue of religion in campaign materials. It is inevitable that the issue of religion is a sensitive issue, and it is a weapon that powerful enough to attack the opponents. This issue in some places (not just in Jakarta) be an interesting discussion, especially in areas with a strong majority basis with candidates coming from minorities.

Indonesian history proves, one of the sources of conflict in the community which led to the anarchic action is a matter of religious conflicts. How many resources are devoted to build tolerance and dialogue, nonetheless this issue like becoming a fire in the hull that could explode at any moment. It is not impossible for the elections this time the matter would be resurfaced and made Indonesia is in a situation of chaos.

This condition is a test in terms of democracy and nation for Indonesia. Can Indonesia passed this test? The hope of course is not only to pass this test in the local elections, but also in the postlocal election period. Maintaining peace in conditions of pluralism in many respects is not easy, and the local elections are one of learning how democratic life in plural conditions. Although not a guarantee, but if Indonesia is able to passed this, it is not impossible peace will be created. Peaceful local elections, peaceful Indonesia. Hopefully realized what was in the fantasy and dreams.

Purwokerto, September 2016

Editor in Chief,

Agus Raharjo 